\title{
Uji Tujuh Genotipe Kedelai Generasi F7 Terhadap Ketahanan Serangan Karat Daun (Phakopsora pachyrhizi) Dengan Metode IWGSR
}

\author{
Author(s): Rona Utama*(1); Nurul Sjamsijah ${ }^{(1)}$ \\ (1) Jurusan Produksi Pertanian, Politeknik Negeri Jember \\ * Corresponding author: ronnarodly@gmail.com
}

\begin{abstract}
ABSTRAK
Serangan karat daun yang disebabkan jamur Phakopsora pachyrhizi merupakan salah satu faktor yang menyebabkan penurunan produksi kedelai hingga $30-60 \%$. Permasalahan ini menuntut pemuliaan untuk merakit varietas unggul baru yang tahan terhadap serangan karat daun. Penelitian ini dilakukan di lahan riset Politeknik Negeri Jember dari bulan Juni - Agustus 2017 menggunakan rancangan acak kelompok non faktorial dengan 3 kali ulangan menggunakan 14 genotipe yang terseleksi dari generasi F2 sampai F6. Keempatbelas genotipe tersebut yaitu 7 genotipe hasil persilangan; P3P2, P2P3, RD, P2D, P3R, P2R, P3D, 4 genotipe tetua; Dering, Rajabasa, Polije-2 dan Polije-3, dan 3 varietas pembanding yaitu Wilis, Malabar dan Ringgit. Parameter yang diuji nilai IWGSR (Internasional Working Group Of Soybean Rust), dan 3 komponen hasil (umur panen, berat 100 biji dan hasil pertanaman). Hasil test menunjukan genotipe P3P2, P2P3, P2R, P3R, P2D, RD, dan P3D memiliki kekebalan serangan karat daun dengan notasi R (Resistance), genotipe P2P3 memiliki umur panen yang genjah yaitu 68,53 HST, dan berat 100 biji pada genotipe RD memiliki hasil yang paling besar yaitu (14,542 g) dan genotipe P3D memiliki hasil $(21,24 \mathrm{~g})$ biji pertanaman.
\end{abstract}

\section{Kata Kunci:}

Genotipe unggul;

Kedelai;

Metode

IWGSR;

Karat Daun;

Keywords: $\quad$ Factor that cause the decreasing of soybean production is disease attack that is caused

Superior

Genotype;

IWGSR

Method;

Soybean;

Soybean Rust;

\section{ABSTRACT} by Phakopsora pachyrhizi which can reduce production by $30 \%-60 \%$. This conditions require plant breeders to assemble new improved varieties that are resistant to leaf rust attack. This research was conducted at research field State Polytechnic of Jember from June to August 2017 with the non factorial Randomized Complete Block Design (RCBD) in three replications. The research used 14 selected soybean genotypes from F2 to F6 generation. Seven genotypes were obtained from the crossing namely: $P 3 P 2, P 2 P 3, P 2 D$, $R D, P 3 R, P 2 R$, and P3D. Four genotypes namely: Dering, Rajabasa, Polije-2 and Polije-3 are the parental genotypes, and three genotypes used as the comparative varieties, are Wilis, Malabar and Ringgit. The International Working Group of Soybean Rust (IWGSR) method proposed parameters to observe including 3 components of yield (harvest age, weight of 100 seeds and crop yield). The results showed that the genotype of $P 3 P 2, P 2 P 3, P 2 D, R D, P 2 R, P 3 R$ and $P 3 D$ had resistance to leaf rust attack with $R$ (Resistance) notation, $P 2 P 3$ genotype had a shorter harvest age of 68,53 DAP, the weight of 100 seeds in RD genotype was $14,542 \mathrm{~g}$, and the highest yield was shown by P3D genotype with $21,24 \mathrm{~g}$ seed per plant. 


\section{PENDAHULUAN}

Kedelai termasuk jenis leguminosae atau kacang - kacangan dan tergolong jenis tanaman pangan yang berpotensial sebagai sumber protein nabati, namun pada waktu tertentu produksi kedelai menurun. Hal ini disebabkan oleh beberapa faktor yaitu adanya penyempitan lahan, anomali iklim dan serangan penyakit karat daun yang disebabkan oleh cendawan Phakopspora pachyrhizi.

Karat daun merupakan penyakit utama pada kedelai dan memiliki sifat obligat yang dapat mengakibatkan menurunnya jumlah polong yang signifikan yaitu sebesar $30 \%-60 \%$, sebab daun yang terserang akan mendapati defoliasi lebih awal (Adisarwanto, 2008).

Permasalahan diatas perlu adanya solusi seperti program pemuliaan yang tujuannya merakit varietas unggul baru yang tahan terhadap serangan penyakit karat daun dengan pengujian International Working of Soybean Rust (IWGSR) dan 3 komponen produksi benih meliputi umur panen, berat 100 biji, dan hasil biji pertanaman yang unggul.

Penelitian ini menguji beberapa genotipe kedelai diantaranya 4 tetua yaitu Dering, Rajabasa, Polije 2 dan Polije 3 dan 3 varietas pembanding yaitu Ringgit, Malabar dan Wilis, serta benih yang telah terseleksi dari generasi F2 sampai F6 yang mempunyai ketahanan terhadap karat daun dan mempunyai karakter yang berbeda dari umur panen, berat 100 dan hasil biji pertanaman adapun diantaranya adalah sebagai berikut RD (Rajabasa X Dering), P2D (Polije 2 X Dering), P2R (Polije $2 \mathrm{X}$ Rajabasa), P2P3 (Polije 2 X Polije 3), P3D (Polije 3 X Dering), P3R (Polije $3 \mathrm{X}$ Rajabasa), dan P3P2 (Polije 3 X Polije 2).

\section{METODOLOGI}

Pelaksanaan Penelitian di lahan percobaan Politeknik Negeri Jember Kecamatan Sumbersari Kabupaten Jember pada bulan Juni - Agustus 2017 dengan Ketinggian $87 \mathrm{~m} \mathrm{dpl}$, suhu rata - rata $25^{\circ}$ $\mathrm{C}-31^{\circ} \mathrm{C}$ dan curah hujan $2.087-2.417$ $\mathrm{mm} /$ tahun (Geofisika, 2017).

Bahan yang digunakan meliputi 4 tetua yaitu Dering, Rajabasa, Polije 2 dan Polije-3 dan 3 varietas pembanding yaitu Ringgit, Malabar dan Wilis, serta benih yang telah terseleksi dari generasi F2 sampai F6 yaitu RD (Rajabasa X Dering), P2D (Polije 2 X Dering), P2R (Polije $2 \mathrm{X}$ Rajabasa), P2P3 (Polije 2 X Polije 3), P3D (Polije 3 X Dering), P3R (Polije $3 \mathrm{X}$ Rajabasa), dan P3P2 (Polije3 X Polije 2) yang mempunyai ketahanan terhadap karat daun dan mempunyai karakter yang berbeda dari umur panen, berat 100 dan hasil biji pertanaman. Pupuk yang diaplikasikan meliputi: Petroorganik, ZA/Urea, $\mathrm{KCl}, \mathrm{SP}-36$, Phonska. Pestisida yang digunakan seperti Insektisida (Decis, Marshal dan Calicron), Furadan 3G, dolomit dan pupuk daun (Gandasil B).

Penelitian memakai Rancangan Acak Kelompok (RAK) non faktorial, 14 genotipe kedelai sebagai perlakuan yang diulang 3 kali, dengan 5 sampel per petak percobaan. Komponen hasil sebagai parameter untuk penunjang keberhasilan pemuliaan antara lain penghitungan nilai IWGSR untuk mengetahui kriteria ketahanan, 3 komponen produksi benih meliputi umur mulai panen, hasil biji pertanaman, dan berat 100 biji. perhitungan sidik ragam jika terdapat perbedaan diuji lanjut dengan DMRT 5\%.

Bentuk matematis Rancangan Acak Kelompok (RAK) adalah (Sudjana, 2001):

$$
Y_{i j}=\mu+\sigma_{i}+\alpha_{j}+€_{i j}
$$

keterangan:

$\mathrm{Y}_{\mathrm{ijk}}$ : Nilai tinjau dari blok ke-i dan genotipe ke-j

$\mu \quad$ : Nilai tengah umum

$\sigma_{\text {I }}:$ Efek blok ke-i

$\alpha_{j} \quad$ : Efek genotipe ke-j

$\epsilon_{\mathrm{ij}}$ : Efek galat penelitian dari blok ke-i dan genotipe ke-j 


\section{HASIL DAN PEMBAHASAN}

Varietas kedelai yang bersifat unggul meliputi produksi tinggi dan tahan terhadap penyakit karat daun (Phakopsora pachyizhizi). Komponen hasil sebagai parameter untuk kriteria tersebut antara lain dengan penghitungan nilai IWGSR untuk mengetahui kriteria ketahanan.
Sedangkan komponen produksi benih yang menentukan keunggulan sifat tanaman kedelai meliputi umur mulai panen, hasil biji pertanaman, dan berat 100 biji. Berikut rangkuman variable pengamatan penelitian yang tertera pada Tabel. 1 dibawah ini.

Tabel 1. Rangkuman Masing - Masing Parameter

\begin{tabular}{clcc}
\hline Genotipe & Umur Panen & Berat 100 biji & Hasil Biji Pertanaman \\
\hline RD & $70.00 \mathrm{ab}$ & $14.54 \mathrm{~d}$ & $17.57 \mathrm{abcd}$ \\
P2R & $72.13 \mathrm{ab}$ & $12.09 \mathrm{bcd}$ & $16.05 \mathrm{abcd}$ \\
P2D & $68.60 \mathrm{a}$ & $11.66 \mathrm{bcd}$ & $13.98 \mathrm{a}$ \\
P3R & $68.67 \mathrm{a}$ & $13.20 \mathrm{~cd}$ & $18.06 \mathrm{abcd}$ \\
P3D & $73.13 \mathrm{ab}$ & $11.06 \mathrm{bcd}$ & $21.24 \mathrm{bcd}$ \\
P2P3 & $68.53 \mathrm{a}$ & $12.29 \mathrm{bcd}$ & $15.79 \mathrm{abc}$ \\
P3P2 & $73.87 \mathrm{~b}$ & $12.25 \mathrm{bcd}$ & $14.55 \mathrm{ab}$ \\
Rajabasa & $83.07 \mathrm{~cd}$ & $9.24 \mathrm{ab}$ & $18.21 \mathrm{abcd}$ \\
Dering & $80.87 \mathrm{c}$ & $12.25 \mathrm{bcd}$ & $19.78 \mathrm{abcd}$ \\
Polije-2 & $74.00 \mathrm{~b}$ & $12.81 \mathrm{~cd}$ & $15.70 \mathrm{abc}$ \\
Polije-3 & $73.53 \mathrm{~b}$ & $13.61 \mathrm{~d}$ & $22.57 \mathrm{~cd}$ \\
Ringgit & $87.47 \mathrm{~d}$ & $7.07 \mathrm{a}$ & $22.93 \mathrm{~d}$ \\
Wilis & $81.67 \mathrm{c}$ & $10.02 \mathrm{abc}$ & $21.18 \mathrm{bcd}$ \\
Malabar & $70.47 \mathrm{ab}$ & $13.92 \mathrm{~d}$ & $13.08 \mathrm{a}$ \\
\hline
\end{tabular}

Keterangan: Angka diikuti dengan huruf yang sama menyatakan berbeda tidak nyata dengan Uji DMRT Taraf $5 \%$.

Tabel 1. menunjukkan perlakuan 14 genotipe yang diuji menghasilkan pengaruh berbeda nyata pada parameter umur panen, berat 100 biji, hasil biji pertanaman. Diduga akibat adanya faktor gen dan faktor lingkungan lebih berpengaruh, pendapat ini didukung oleh Noorhadi, (2003) menyatakan bahwa selain faktor genetik, faktor lingkungan seperti kelembaban dan suhu di sekitar tanaman sangat mempengaruhi perkembangan dan hasil tanaman saat proses pembentukan bunga dan pengisian polong. Selama tanaman beradaptasi akan mengalami perubahan fisiologis dan morfologis kearah yang sesuai dengan lingkungan baru untuk tumbuh Jumin, (2005). Karamoy, (2009) menyatakan salah satu faktor pendukung proses fotosintesis adalah ketersediaan cahaya yang cukup, dimana hasil fotosintesis selanjutnya akan ditranslokasikan ke sink yaitu bunga, buah dan biji.

Curah hujan tinggi saat fase berbunga mengakibatkan bunga tidak dapat melakukan pembuahan sebab bunga mengalami kerontokan, sehingga jumlah polong yang terbentuk juga tidak optimal dan menyebabkan umur mulai panen menjadi lebih panjang karena proses fotosintesis yang kurang optimal sehingga mengakibatkan masaknya polong menjadi terhambat ataupun terlanjur busuk karena suhu dan kelembapan yang rendah, suhu yang sesuai untuk perkembangan kedelai menurut Widyawati, (2008) antara $20^{\circ} \mathrm{C}$ $30^{\circ} \mathrm{C}$. 


\section{Umur Panen}

Pada Tabel 1. Menunjukkan bahwa hasil persilangan $\mathrm{P} 2 \mathrm{P} 3, \mathrm{P} 2 \mathrm{D}$, dan $\mathrm{P} 3 \mathrm{R}$ mempunyai umur panen yang lebih genjah daripada genotipe lain dibandingkan dengan varietas pembanding Malabar (70.47 HST) dengan rata-rata umur panen 68.53, 68.60, dan 68.67 HST. Hasil persilangan P2P3, P2D, dan P3R menunjukkan perbedaan yang tidak nyata dengan RD (70.00 HST), P2R (72.13 HST), P3D (73.13 HST), akan tetapi menunjukkan perbedaan yang nyata dengan P3P2 (73.87 HST). Sedangkan hasil persilangan $\mathrm{P} 3 \mathrm{P} 2$ memiliki rata-rata umur panen yang lebih lama daripada hasil persilangan lain dan varietas pembanding Malabar.

Haryati and Rahadian, (2012) menyatakan bahwa umur panen kedelai dikelompokkan menjadi tiga yaitu umur genjah $<85$ hari, umur sedang $85-90$ hari dan umur panjang $>90$ hari. Sesuai umur panen 7 genotipe hasil persilangan yang menunjukkan umur panen genjah adalah genotipe $\mathrm{P} 2 \mathrm{P} 3$ dengan umur panen rerata 68.53 HST dan yang paling lambat adalah P3P2 dengan umur panen rerata 73.87 HST. Noorhadi, (2003) selain faktor genetik, faktor lingkungan seperti kelembaban dan suhu di sekitar tanaman memberikan efek pada perkembangan dan hasil tanaman dalam proses pembentukan bunga dan pengisian polong.

\section{Berat 100 Biji (Gram)}

Tabel 1. menyatakan bahwa genotipe $\mathrm{RD}$ memiliki hasil rerata tertinggi yaitu 14.542 g. Sedangkan genotipe Ringgit memiliki rerata yang paling kecil $7.069 \mathrm{~g}$.

Genotipe hasil persilangan RD $(14.54 \mathrm{~g})$ menunjukan berbeda tidak nyata terhadap genotipe P2P3 (12.29), P2D (11.66), P3R (13.20), P2R (12.09), P3D (11.06), P3P2 (12.25), Malabar (13.92), Polije-3 (13.61), Polije-2 (12.81), dan Dering (12.25) akan tetapi berbeda nyata dengan Rajabasa (9.24) sebagai salah satu tetuanya, Wilis (10.02) dan Ringgit (7.07).

Adisarwanto, (2008) mengungkapkan bahwa ukuran biji kedelai dikelompokan menjadi tiga kelompok yaitu berbiji kecil ( $<10 \mathrm{~g} / 100$ biji), berbiji sedang (10 - $12 \mathrm{~g} / 100 \mathrm{biji})$, dan berbiji besar (13 -18 g/100 biji). Arifiana and Sjamsijah, (2017) mengungkapkan kebutuhan air dan unsur hara yang optimal akan memaksimalkan tanaman dalam pembentukan pengisian biji sehingga ukuran biji dan berat biji akan bertambah besar.

\section{Hasil Biji Per Tanaman (g)}

berdasarkan Tabel 1. Berat biji pertanaman untuk persilangan genotipe P3D memiliki rerata hasil tertinggi yaitu $21.24 \mathrm{~g}$ dari pada hasil persilangan lainya. Genotipe P3D menunjukan perbedaan yang tidak nyata pada genotipe $\mathrm{P} 2 \mathrm{P} 3$ (15.79), P3R (18.06), RD (17.57), P2R (16.05), P2P3 (15.79), Polije-3 (22.57), Polije-2 (15.70), Dering (19.78), Rajabasa (18.21) dan wilis (21.18) akan tetapi berbeda nyata dengan genotipe P2D (13.98), Malabar (13.08) dan Ringgit (22.93).

Sumardin, (2014) menyatakan faktor yang mempengaruhi hasil atau berat biji pertanaman adalah faktor genetik dan lingkungan seperti adanya serangan penyakit karat daun. Polije-3 adalah tetua yang mempunyai potensi hasil yang tinggi yaitu 4,17 ton/ha. Sedangkan genotipe Dering merupakan tetua yang mempunyai sifat tahan terhadap penyakit karat daun (Istiqomah, dkk 2015).

Arifin, (2011) menyatakan hasil biji setiap tanaman disebabkan oleh genetik, teknik produksi dan faktor lingkungan tumbuh, seperti perbedaan kesuburan tanah, cuaca, komponen hasil seperti jumlah buku subur batang utama, biji per polong, skala biji, tinggi tanaman, banyak cabang, masa penyusunan polong dan pengisian biji serta persentase biji yang 
teraborsi.

\section{NILAI IWGSR}

Pengamatan dilaksanakan tiap individu daun tanaman kedelai dengan sistem IWGSR (Yang, 1977) adalah sebagai berikut:

1. Angka pertama menunjukan kedudukan daun kedelai

- Nilai $1=1 / 3$ daun posisi bawah

- Nilai $2=1 / 3$ daun posisi tengah

- Nilai $3=1 / 3$ daun posisi atas

2. Angka kedua menunjukan kerapatan bercak daun karat pada daun

- Nilai $1=$ tidak terdapat bercak karat

- Nilai 2 = ringan $(1-8$ bercak $/ \mathrm{cm})$

- Nilai $3=$ sedang $(9-16$ bercak $/ \mathrm{cm})$

- Nilai 4 = berat (lebih dari 16 bercak $/ \mathrm{cm}$ )

3. Angka ketiga menunjukan reaksi daun terhadap penyakit karat

- Nilai 1 = tanpa pustula (bercak)

- Nilai 2 = bercak tak berspora

- Nilai $3=$ bercak berspora

Penilaian IWGSR menyatakan angka kedua yang menunjukan kerapatan bercak seluas $1 \mathrm{~cm}^{2}$ pada daun kedelai dan diberi skor sesuai dengan angka yang ditentukan. Penularan penyakit diamati satu kali didaun pertama setiap tanaman pada umur $30,40,50,60,70$ dan 80 hari setelah tanam. Cara observasi terkait penularan penyakit tertera pada Gambar 1.

Plastik transparan yang sudah digaris kotak - kotak seluas $1 \mathrm{~cm}^{2}$ diletakkan dibagian tengah tulang daun yang diamati. Jumlah bercak yang terdapat di dalam garis kotak-kotak plastik transparan tersebut dirata - ratakan $\left(\right.$ per $\left.\mathrm{cm}^{2}\right)$ seperti Gambar berikut.
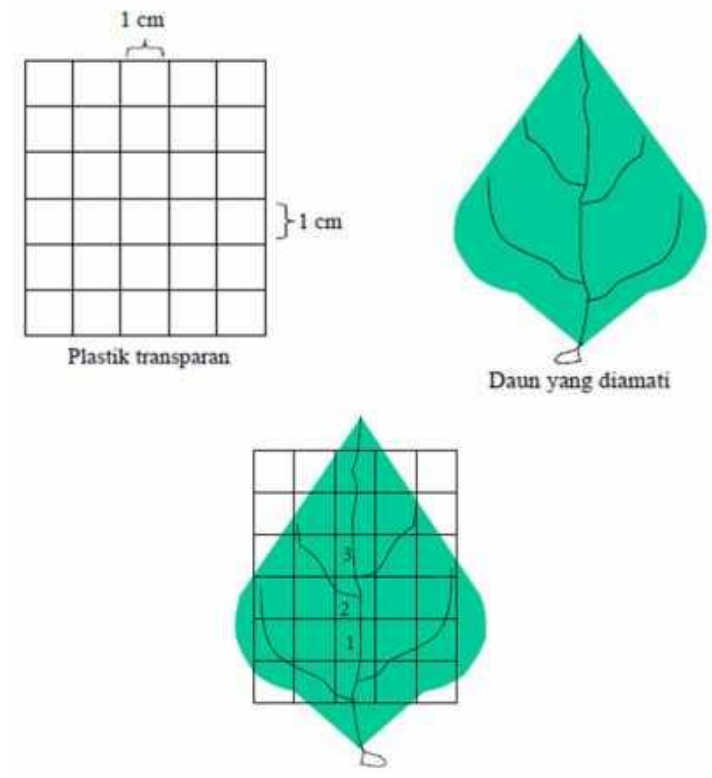

Gambar 1. Pengamatan bercak penyakit karat pada daun kedelai

Indiati, (2004) menyatakan gejala karat daun kedelai umumnya tampak pada tanaman umur 20 - 30 hari, berupa bercak yang berisi uredium dikelilingi oleh halo warna kuning. Tabel 2 menunjukkan pada umur 30 HST belum ada serangan penyakit karat daun, dilihat dari hasil skoring yang menunjukkan nilai 011 . Pada umur 40 HST serangan penyakit karat mulai terlihat pada 3 genotipe yaitu $\mathrm{P} 2 \mathrm{P} 3$, P2P3, P2D dengan skor 122 yang artinya serangan terjadi pada $1 / 3$ daun bagian bawah nilai (1) dengan kerapatan bercak sedikit $\left(1-8\right.$ bercak $\left./ \mathrm{cm}^{2}\right)$ nilai (2) dan bercak tak berspora nilai (2). Begitu pula pada umur 50 HST sampai umur 60 HST, 7 genotipe hasil persilangan mempunyai nilai yang sama yaitu 122 , sedangkan pada umur 70 HST sampai dengan umur 80 HST serangan penyakit karat mulai ada peningkatan hal ini dibuktikan dengan hasil skoring dominan yang menunjukkan angka 223 yang artinya serangan karat sudah mencapai $1 / 3$ daun bagian tengah dengan nilai (2) kerapatan bercak per $\mathrm{cm}^{2}$ sedikit $\left(1-8\right.$ bercak $\left./ \mathrm{cm}^{2}\right)$ dengan nilai (2) dan bercak berspora dengan nilai (3). 
Tabel 2. Pengamatan nilai IWGSR (International Working Group of Soybean Rust)

\begin{tabular}{cccccccccccccccc}
\hline Tanggal & HST & RD & P2R & P2D & P3R & P3D & P2P3 & P3P2 & R & D & P2 & P3 & Ri & W & M \\
\hline 29 Juni 2017 & 30 & 011 & 011 & 011 & 011 & 011 & 011 & 011 & 011 & 011 & 011 & 011 & 011 & 011 & 011 \\
09 Juli 2017 & 40 & 111 & 111 & 122 & 111 & 111 & 122 & 122 & 111 & 111 & 111 & 111 & 111 & 111 & 111 \\
19 Juli 2017 & 50 & 122 & 122 & 122 & 122 & 122 & 122 & 122 & 122 & 122 & 111 & 111 & 111 & 111 & 112 \\
29 Juli 2017 & 60 & 122 & 122 & 122 & 122 & 122 & 122 & 122 & 122 & 122 & 111 & 222 & 122 & 122 & 122 \\
09 Agt 2017 & 70 & 123 & 222 & 122 & 223 & 123 & 123 & 123 & 123 & 223 & 223 & 223 & 223 & 223 & 123 \\
19 Agt 2017 & 80 & 223 & 223 & 223 & 223 & 223 & 223 & 223 & 223 & 223 & 223 & 223 & 223 & 223 & 223 \\
\hline
\end{tabular}

Keterangan : Angka pertama menunjukkan kedudukan daun $(1=1 / 3$ daun bagian bawah, $2=1 / 3$ daun bagian tengah, $3=1 / 3$ daun bagian atas). Angka kedua menunjukkan kerapatan bercak karat pada daun 1 $=$ tidak terdapat bercak karat $2=$ bercak karat sedikit $\left(1-8\right.$ bercak $\left./ \mathrm{cm}^{2}\right) 3=$ bercak karat sedikit $(9$ -16 bercak $/ \mathrm{cm}^{2}$ ) 4 = bercak karat sedikit (lebih dari 16 bercak $/ \mathrm{cm}^{2}$ ). Angka ketiga menunjukkan reaksi daun terhadap penyakit karat $1=$ tanpa pustule (bercak) $2=$ bercak tak berspora $3=$ bercak berspora (uredospora)

Menurut (Rumbiak, 2011) Pertumbuhan spora dan penembusan spora memerlukan air bebas dan terbentuk suhu $8-28^{\circ} \mathrm{C}$. Uredia ada $9-10$ hari setelah penularan, dan urediospora diproduksi setelah 3 minggu. Keadaan lembab yang panjang dan masa dingin diperlukan dalam proses menginfeksi daun - daun dan sporulasi. Pemencaran urediniospora didukung oleh angin diwaktu hujan. Gejala penyakit karat daun yaitu bercak berisi eredia (badan buah yang memproduksi spora) berwarna coklat kemerahan seperti karat yang berada pada daun bercak ini meningkat ke daun - daun diatasnya dengan bertambahnya umur tanaman. Bercak utama terdapat pada posisi bawah daun.

Serangan penyakit karat daun dimulai dari daun bawah dan merambat ke daun - daun diatasnya hal ini terjadi karena daun pada bagian bawah merupakan daun yang tua serta ketahanannya menurun sehingga peka terserang karat daun.

Proses infeksi jamur karat pada daun kedelai adalah melalui stomata dimana uredospora jamur karat kedelai akan berkecambah dan menyebar dipermukaan daun dan bulunya akan masuk kedalam jaringan daun melalui stomata sehingga mengakibatkan daun rontok sebelum waktunya serta memberikan pengaruh negatif terhadap perkembangan dan pertumbuhan tanaman kedelai (Sunarto dan Soesanto, 2004).

Jamur Phakopsora pachyrhizi dapat berkembang dan menginfeksi tanaman kacang - kacangan salah satunya kedelai apabila suhu di sekitar tanaman kurang dari $27,5^{\circ} \mathrm{C}$. Barus (2007) menyatakan bahwa infeksi tidak dapat terjadi bila suhu lebih tinggi dari $27,5^{\circ} \mathrm{C}$ serta penyakit karat yang lebih berat terjadi pada tanaman kedelai pada musim penghujan. Pada lahan percobaan yang terletak di lahan Politeknik Negeri Jember suhu rata - rata adalah $27,34^{\circ} \mathrm{C}$ hal ini juga sebagai faktor lain yang mendukung ke tujuh genotipe tidak terserang. Penyakit karat daun dapat mengakibatkan menurunnya hasil kedelai yang signifikan yaitu mencapai $30-60 \%$ dan berakibat menurunya kualitas biji kedelai, selain itu tanaman kedelai yang terserang penyakit ini menghasilkan biji lebih kecil Adisarwanto, (2008). Cendawan $P$. pachyrhizi merupakan jenis parasit yang memiliki sifat obligat, yang menjadikan tanaman kedelai menjadi inang utamanya jika di lapangan tidak terdapat tanaman kedelai, spora hidup pada tanaman inang lain atau di tanah namun tidak bertahan cukup lama, bisa disimpulkan bahwa tanaman kedelai merupakan tanaman inang utama cendawan ini sehingga perlu 
penanganan baik dari faktor genetik tanaman maupun lingkungan tumbuh (Sumartini, 2016).

Berikut adalah hasil pengamatan 14 genotipe tanaman kedelai yang diuji antara lain Ringgit, wilis, Malabar, Dering, Rajabasa, Polije-2, Polije-3, dan persilangan RD, P2D, P2R, P2P3, P3D, P3R, P3P2 diperoleh notasi $R$ (Resisten) seperti pada Tabel 3.

Tabel 3. Hasil Pengamatan IWGSR (International Working Group of Soybean Rust)

\begin{tabular}{lc}
\hline Genotipe & Notasi \\
\hline RD & $\mathrm{R}$ \\
P2R & $\mathrm{R}$ \\
P2D & $\mathrm{R}$ \\
P3R & $\mathrm{R}$ \\
P3D & $\mathrm{R}$ \\
P2P3 & $\mathrm{R}$ \\
P3P2 & $\mathrm{R}$ \\
Rajabasa & $\mathrm{R}$ \\
Dering & $\mathrm{R}$ \\
Polije-2 & $\mathrm{R}$ \\
Polije-3 & $\mathrm{R}$ \\
Ringgit & $\mathrm{R}$ \\
Wilis & $\mathrm{R}$ \\
Malabar & $\mathrm{R}$
\end{tabular}

Keterangan: R (Resisten)

Berdasarkan Tabel 3. Ke tujuh genotipe hasil persilangan menunjukkan sifat tahan terhadap penyakit karat daun dimana hasil penghitungan nilai IWGSR diperoleh notasi $\mathrm{R}$ (Resisten atau Tahan) hal ini dikarenakan sifat ketahanan yang dimiliki suatu tanaman, diperoleh dari sifat asli dari indukannya kepada keturunannya yang berasal dari genotipe Dering, Rajabasa, Polije 2 dan Polije 3 dan tidak menuntut kemungkinan adanya faktor lingkungan dapat memberikan pengaruh terhadap sifat ketahanan dari tanaman, hal ini didukung oleh pendapat Noorhadi, (2003) menyatakan bahwa pengaruh gen, efek lingkungan terutama kelembaban dan suhu di areal tanaman memiliki efek pertumbuhan dan hasil tanaman. Istiqomah, dkk (2015) menyatakan bahwa hasil uji ketahanan terhadap karat daun genotipe DV/2984330 (Dering) kebal terhadap karat daun, berlandaskan sistem penilaian IWGSR.

Genotipe nilai 222 terdapat serangan bercak tidak berspora dan ringan di sepertiga bagian tengah. Rajabasa memiliki sifat agak tahan terhadap karat daun. Menurut Aisyah, (2014) mekanisme ketahanan terhadap serangan karat daun dimiliki oleh genotipe Rajabasa dan Dering.

\section{KESIMPULAN}

1. Ke tujuh genotipe hasil persilangan P3P2, P2P3, P2R, P3R, P2D, RD, dan P3D memiliki ketahanan terhadap serangan penyakit karat daun dengan notasi R (Resisten)

2. Genotipe P2P3 memiliki umur panen yang genjah $\pm 68,53$ HST, berat 100 biji pada genotipe RD menghasilkan berat tertinggi $\pm 14,542 \mathrm{~g}$ dan hasil biji pertanaman genotipe P3D mempunyai berat tertinggi daripada hasil persilangan yang lain yaitu $\pm 21,24 \mathrm{~g}$

3. Ke tujuh genotipe tersebut dapat direkomendasikan sebagai calon varietas unggul baru guna membantu pemerintah dalam memenuhi kedelai nasional.

\section{DAFTAR PUSTAKA}

Adisarwanto, T. (2008). Budidaya 镐 Kedelai Tropika.

Aisyah, S. (2014). Pecandraan Sifat Agronomi Delapan Genotipe Kedelai Tahan dan Agak Tahan Patogen Karat Daun (Universitas Negeri Jember).

Arifiana, N. B., \& Sjamsijah, N. (2017). EQ Respon Seleksi Tanaman F3 pada Beberapa Genotipe Tanaman 
Kedelai (Glycine max (L.) Merrill). Agriprima, Journal of Applied Agricultural Sciences, 1(1), 50-58.

Arifin, Z. (2011). Deskripsi Sifat 琶Agronomik Berdasarkan Seleksi Genotipe Tanaman Kedelai dengan Metode Multivariat. Agriprima, Journal of Applied Agricultural Sciences, 3(5).

Barus, A. (2007). Uji Efektifitas Beberapa 尌 Pestisida Nabati untuk Mengendalikan Penyakit Karat Daun (Phakopsora pachyrhizi) Pada Tanaman Kacang Kedelai (Glycine max L. Merril) (Universitas Sumatera Utara).

Geofisika, B. M. K. (2017). Badan EMeteorologi Klimatologi dan Geofisika, 2017.

Haryati, Y., \& Rahadian, D. (2012). 期Penampilan Galur Harapan Kedelai Toleran Kekeringan Di Kabupaten Garut Jawa Barat. Agrin, 16(1).

Indiati, S. W. (2004). Penyaringan dan 钢 Mekanisme Ketahanan Kacang Hijau MLG-716 Terhadap Hama Thrips. Jurnal Litbang Pertanian, 23(3), 101.

Istiqomah, N., \& Krismawati, A. (2015). 尌 Hasil Varietas Unggul Kedelai Mendukung Peningkatan Produksi Kedelai di Jawa Timur. Prosiding Seminar Hasil Penelitian Tanaman Kacang Dan Umbi, 163-168.

Jumin, H. B. (2005). Dasar-Dasar Agronomi. Edisi Revisi. Divisi Buku Perguruan Tinggi.

Karamoy, L. T. (2009). Hubungan Iklim 钢 dengan Pertumbuhan Kedelai (Glycine max L Merrill). Soil
Environment, 7(1), 65-68.

Noorhadi, S. (2003). Kajian Pemberian Air dan Mulsa Terhadap Iklim Mikro pada Tanaman Cabai di Tanah Entisol. Jurnal Ilmu Tanah Dan Lingkungan, 4(2003).

Rumbiak, B. V. (2011). Intensitas 豇 Penyakit Karat Daun (Phakopsora pachyrhizi Syd) pada Tanman Kedelai (Glycine max (L) Merril) Di Kampung Sanggaria Distrik Arso Kabupaten Keerom. Universitas Negeri Papua.

Sudjana, N. (2001). Desain Analisis Eksperimen.

Sumardin. (2014). Pertumbuhan dan 顽 Hasil Beberapa Varietas Kedelai (Glicine max L.)Terhadap Jenis Pupuk Pelengkap Cair. Universitas Taman siswa.

Sumartini, S. (2016). Penyakit Karat pada 顽 Kedelai dan Cara Pengendaliannya yang Ramah Lingkungan. Jurnal Penelitian Dan Pengembangan Pertanian, 29(3), 107-112.

Sunarto dan Soesanto, L. (2004). Hasil QDan Ketahanan Terhadap Penyakit Karat Delapan Genotipe Kedelai. (Universitas Jendral Soederman Purwokerto.).

Widyawati, W. (2008). Kajian 基 Perkembangan Varietas Unggul dan Perbenihan Kedelai (Glycine max (L.) Merrill.). (Institut Pertanian Bogor).

Yang, C. Y. (1977). The IWGSR Rust 钢 Rating System. Soybean Rust Newsletter, pp. 4-6. 